ought to find their home with nerve-cells governing the bloodvessels, take up with nerve-cells governing the dilator structures of the pupil.

And if we turn to other nerves, greater aberrations are found. We have seen that the nerves running from the central nervous system to involuntary structures may be divided into two sets : the sympathetic nerves on the one hand, and the cranial and sacral nerves on the other. An important cranial nerve is the vagus; it causes, when in action, cessation of the heart-beat, contraction of the cesophagus, contraction or inhibition of the stomach, and various other effects. It does not send nerve-fibres to any of those structures of the head which we have seen the sympathetic ganglion at the top of the neck -the superior cervical ganglion-so liberally supplies. And yet the vagus nerve, if it has a proper opportunity of growing into the superior cervical ganglion, will do so, and there establish connections with the nerve-cells. Thus the nerve which properly exercises control over certain viscera in the thorax and abdomen is capable of exercising control over structures in the head, such as the iris, the blood-vessels and the glands. The details of the process, with which I will not trouble you, do not afford any clear evidence that the nervefibres of the vagus pick and choose amongst the nerve-cells of the superior cervical ganglion; the fibres appear rather to form their terminal branches around any kind of nerve-cell, so that, in fact, the action which the nerve-fibre will in future bring about depends, not on any intrinsic character of its own, but upon the nature of the action carried on by the nerve-cell. The nerve-cell may cause secretion from a gland, or contraction of a blood-vessel, or dilation of the pupil, or movement of hairs; whichever action it causes, the nerve-fibre which joins it from the vagus nerve can cause for the future, and it can cause no other. In this case, then, we arrive at results which are hopelessly at variance with the view that the nerve-fibres and nerve-cells of the involuntary nervous system are divided into classes which are fundamentally different. In other words, that theory which is spoken of as the theory of specific nerve-energy does not apply here.

But if this is so, how are we to account for the selective power shown by the sympathetic nerve-fibres which $I$ have mentioned earlier? That the different classes of nerve-fibres and nerve-cells with which we are dealing have not those deep and inherent differences which are required by the theory of specific nerve-energy is, it seems to me, certain. Nevertheless, there may be some differences of a comparatively superficial nature which suffice to explain the selective activity observed. We may suppose that a re-growing nerve-fibre will in favourable circumstances join a nerve-cell the function of which is the same as that of its original cell, but that if there are hindrances in the way of this return to normal action, and if the conditions are favourable for joining a nerve-cell acting on some other tissue, why then it will join this. It is as if it had a preference, but did not care overmuch. We might perhaps express the facts by saying that there are different varieties of pre-ganglionic fibres, but no species.

We have been speaking so far of the nerve-fibres which run from the brain and spinal cord to the peripheral nerve-cells. The nerve-fibres which run from the peripheral nerve-cells have also, there is reason to believe, a large measure of indifference as to the kind of work they perform. The limits of this indifference have yet to be investigated.

I have said earlier that in mammalia nerve-fibres are not known to run to connective-tissue cells or to epidermic cells. But in some lower vertebrates certain connective-tissue cells are under the control of the central nervous system. Thus in the frog the pigmented connective-tissue cells, which play a large part in determining the colour of the skin, can be made to contract or to rearrange their pigment granules-and so change the colour of the skin-by excitation of certain nerves. In all probability, the motor nerve-fibres to the pigment-cells belong to the same class as the nerve-fibres which run to the arteries and to the glands-i.e. they belong to the autonomic system. We have seen that unstriated muscle-cells and gland-cells in different parts of the body are by no means equally supplied with motor nerve-fibres, and it may be that in mammals there are certain connective-tissue cells which receive motor nervefibres. Further, if it is true, as it well may be, that nerve-fibres which run to a gland are capable in favourable conditions of making connections with a blood-vessel, it is not beyond hope that either kind of nerve-fibre may experimentally, by offering it favourable conditions, be induced to join connective-tissue cells.

The factors which determine whether a particular tissue or part of a tissue is eventually supplied with nerve-endings, and the degree of development of these, are the factors which determine evolution in general. In the individual, it is exercise of function which leads to the development of particular parts ; in the race, it is the utility of this development which leads to their preservation. And so it is conceivable that in some lower vertebrate at some time, the autonomic nervous system may have developed especially in connection with those tissues which appear in ourselves to be wholly unprovided with motor nervefibres.

I am tempted, before ending, to make a slight digression. Those who have occasion to enter into the depths of what is oddly, if generously, called the literature of a scientific subject, alone know the difficulty of emerging with an unsoured disposition. The multitudinous facts presented by each corner of nature form in large part the scientific man's burden to-day, and restrict him more and more, willy-nilly, to a narrower and narrower specialism. But that is not the whole of his burden. Much that he is forced to read consists of records of defective experiments, confused statement of results, wearisome description of detail, and unnecessarily protracted discussion of unnecessary hypotheses. The publication of such matter is a serious injury to the man of science; it absorbs the scanty funds of his libraries, and steals away his poor hours of leisure.

Here I bring my remarks to a close. I have endeavoured to give as clearly as possible what seem to me to be the conclusions which logically follow from certain data, but I would not have you believe that I regard them as representing more than the immediate point of view. As the wise man said : "Hardly do we guess aright at things that are upon earth, and with labour do we find the things that are before us."

\section{AMERICAN ASSOCIATION FOR THE ADVANCEMENT OF SCIENCE.}

THE presidential addresses delivered before the Sections of Zoology and Botany of the American Association, by Profs. S. H. Gage and C. R. Barnes, respectively, are printed in Science of September 8. The subjects were "The Importance and the Promise in the Study of Domestic Animals" and "The Progress and Problems of Plant Physiology" and the subjoined extracts show some of the points dealt with. Abstracts of several other sectional addresses have already appeared in NATURE, p. 515 .

Prof. Gage described a few ways in which the study of domestic animals has thrown light on the problems confronting mankind in his social ideals, in preventive medicine, in physiology and hygiene, in embryology and comparative anatomy and in the doctrine of the evolution of organic forms. He showed that, with the higher forms at least, that is the forms most closely related to man, and with whose destiny his own economic, hygienic and social relations are most closely interwoven, the domestic animals have in the past and promise in the future to serve the best purpose because of the abundance of the material in quite widely separated groups of animals which long have been and still are under greatly differing conditions and surroundings; and, finally, because this material is plentiful and under control, and thus may be studied throughout the entire life cycle.

There has been and still is too great a tendency in biology to study forms remote and inaccessible. This is, perhaps, partly due to the fascination of the unknown and the distant, and the natural depreciation of what is at hand. But study of these supposedly generalised types has proved more or less disappointing. No forms now living are truly primitive and generalised throughout. They may be in parts, but in parts only. The stress of countless ages has compelled them to adjust themselves to their changing environment, to specialise in some directions so far that the clue through them to the truly primitive type is very much tangled or often wholly lost. Indeed, every group is in some features primitive.

As any complete study requires much material at all stages the higher forms must be of the domesticated groups, or wild

$$
\text { NO. I } 562 \text {, VOL. 60] }
$$


forms must be practically domesticated for the time being to supply the material.

It may be objected, also, that in the investigation of domesticated forms sordid interests will play too prominent a part. No doubt to the true scientific man the study of zoology for its own sake, that is, for an insight into the fundamental laws of life, is a sufficient incentive and reward. Judging from the past, the study of the domestic animals in any other way than in a scientific spirit and by the scientific method will prove barren; but studied in that spirit and by that method the result has always justified the effort, and has thrown as much, if not more, light upon biological problems than an equally exact study of a wild form.

Therefore, while purely practical ends can never supply the inspiration to true scientific work, still surely no scientific man could feel anything but happiness that his work had in some ways added to the sum of human well-being. Perhaps no one has expressed so well the sympathy of a scientific man with his fellow-men as Pasteur in the preface to his work on the silkworm diseases: "Although I devoted nearly five consecutive years to the laborious experimental researches which have affected my health, I am glad that I undertook them. . . . The results which I have obtained are perhaps less brilliant than those which I might have anticipated from researches pursued in the field of pure science, but $I$ have the satisfaction of having served my country in endeavouring, to the best of my ability, to discover a remedy for great misery. It is to the honour of a scientific man that he values discoveries which at their birth can only obtain the esteem of his equals, far above those which at once conquer the favour of the crowd by the immediate utility of their application; but in the presence of misfortune it is equally an honour to sacrifice everything in the endeavour to relieve it. Perhaps, also, I may have given young investigators the salutary example of lengthy latours bestowed upon a difficult and ungrateful subject."

In conclusion Prof. Gage summarised his address by saying : However necessary and desirable it may have been in the past that the main energy of zoologists should be employed in the description of new species and in the making of fragmentary observations upon the habits, structure and embryology of a multitude of forms, I firmly believe that necessity or even desirability has long since passed away, and that for the advancement of zoological science the work of surpassing importance confronting us is the thorough investigation of a few forms from the ovum to youth, maturity and old age. And I also firmly believe that, whenever available, the greatest good to science, and thus to mankind, will result from a selection of domesticated forms for these thorough investigations.

In the Section of Botany, Prof. Barnes discussed the chief features of plant physiology in which notable progress has been making during the last decade. The great advances in plant chemics and physics ; the progress in the investigation of causes of plant form : the widening ideas of the property of irritability; the investigation of the social relations of plants, and the minute study of cell action in spite of their diversity, have one great end in view. This is nothing less than the solution of the great problemthe fundamental problem-of plant physiology as of animal physiology, namely the constitution of living matter. Entrenched within the apparently impregnable fortress of molecular structure this secret lies hid. The attacks upon it from the direction of physical chemistry and physiological morphology, of irritability, of ecology and of cytology are the concentrating attacks of various divisions of an army upon a citadel some of whose outer defences have already been captured. The innumerable observations are devised along parallel lines of approach, and each division of the army is creeping closer and closer to the inner defences, which yet resist all attacks and hide the long. sought truth.

One outer circle of defences yet remains untaken, and until that falls it would seem that there is little hope of capturing the inner citadel. More must be known of the constitution of dead substances chemically related to the living ones. When the students of chemistry can put the physiologists into possession of the facts regarding dead proteids, the attacks will be renewed more directly, with greater vigour and greater hope of success.

It is not possible to prove to-day that life and death are only a difference in the chemical and physical behaviour of certain compounds. It is safe to say that the future is likely to justify such an assertion.

NO. I 562 , VOL. 6o]

\section{UNIVERSITY AND EDUCATIONAL}

$$
\text { INTELLIGENCE. }
$$

CAMBRIDGE.-Eleven county and borough councils have arranged with the Board of Agricultural Studies to make grants for the maintenance of the new department of Agriculture established under the direction of Prof. Somerville. The first list of lectures issued by the Board includes some seventeen courses.

IN the valedictory address delivered by Dr. Hill on vacating the office of Vice-Chancellor, reference was made to the fact that before the close of the academic year the contributions to the Benefaction Fund amounted to upwards of $50,000 l$; ; also that a commencement has been made with the new Geological Museum. The Museum will cost about 44,000 l, of which sum the fund raised as a memorial to Prof. Sedgwick will supply 27,000l.

A TECHNICAL and mining college is to be established at Wigan at an estimated cost of $40,000 l$.

THE Rev. J. F. Cross has been appointed professor of mathematics at St. John's University, Winnipeg.

Prof. A. McAdie has been appointed honorary lecturer on meteorology in connection with the Berkeley Astronomical Department of the University of California.

Mr. THEODORE MORISON has been appointed principal of the Aligarh Mahomedan College. The new principal, who is at present in this country, has been authorised to select two new professors to take out with him.

PROF. WAGSTAFF will lecture on geometry at Gresham College from October Io to I3, and the Rev. E. Ledger's course of lectures on astronomy at the same institution will take place from November I4 to 17 .

THE degree of Doctor of Pharmacy has just been conferred by the University of Paris for the first time. The recipient is M. Lacourt, whose graduation thesis was entitled " Historical, Chemical and Bacteriological Study of the Versailles Water."

THE fifteen universities of France together have a total of 27,080 students, of whom 12,059 belong to Paris. The total expenditure is $13,859,500$ francs, so that the average cost of the education of each student is $5 \mathrm{fr}$ francs (a trifle over $20 \mathrm{l}$.). To meet this expense the universities have revenues amounting collectively to $2,093,700$ francs; legacies, donations, \&c., amount to I, II, 600 francs; therefore a deficit of $10,524,200$ francs (equivalent to nearly $15 l$. for each student) has each year to be made up by the State.

AT the half-yearly meeting of the court of governors of Owens College, Manchester, held on Tuesday last, the following resolution was carried by a majority of two:- "That, subject to such limitations and conditions as the council may from time to time determine, and subject to the council being able to make satisfactory provision for a separate instruction in such cases as the council consider necessary, the court is of opinion that it would be desirable to admit women students to the course of study which would qualify them for medical degrees and practice."

AcCording to the Allahabad Pioneer Mail, during the past year no fewer than $1 \mathrm{r}, 000$ candidates presented themselves for the various examinations of the Madras University, and of these slightly over 4000 were successful. The fees paid by candidates amounted to nearly Rs. I, 87,000; while sundry items, including about Rs. IO,000 interest on Government securities, swelled the income of the University to a little over two lakhs of rupees. The total expenditure for the year came up to Rs. I, 80,000, of which sum Rs. I, 38,000 were absorbed by examiners' fees. The Arts Examinations, as usual, yielded the greatest portion of the University income - the total fees realised from candidates amounted to over one and a half lakhs of rupees, while payments to examiners came up to Rs, 90,000. The Law Examin. ations yielded a quarter of a lakh of rupees, while the examiners fees only amounted to slightly over half this sum. The Medical and Engineering Examinations, however, are conducted at a loss; but, after balancing receipts and expenditure, the University realised a net profit during the past year of Rs. I0,000, without reckoning the Rs. 10,000 accruing as interest from Government securities. 